\title{
Travel-to-school distances in Sweden 2000-2006: - Changing school geography with equality implications
}

\author{
Eva Andersson*, Bo Malmberg*, John Östh*'**
}

\begin{abstract}
*Dept. of Human Geography, SE-106 91 Stockholm, Stockholm Univ., SWEDEN. tel. +46 8164866 eva.andersson@humangeo.su.se (corresponding author), +46 81648 53, bo.malmberg@humangeo.su.se **Dept. of Social and Economic Geography, SE-754 20 Uppsala, Uppsala Univ., SWEDEN. tel. +46 1847173 88, john.ost@kultgeog.uu.se.
\end{abstract}

\begin{abstract}
Twenty years ago the Swedish school system underwent serious change in that students were given the right to choose their school, though those living near each school had priority. Since then, there has been a new geographical debate concerning where students live and go to school and possible implications of this on student educational achievement and educational equality, as well as on students' daily lives. In studies of changes in the school system, travel distances to school have so far been less studied in the Swedish context. In this paper we will analyze the changes in distance to school for 15-year-olds, from 2000 to 2006, in order to identify who, and in which context, is travelling shorter/longer distances, and thus performing a school choice. We use register data from the database PLACE, Uppsala University. The focus is not on effects on achievement, nor school composition, but instead on the difference in ability/possibility of using school choice as measured by distance. A time-geography approach concerning variation in constraints between students is used. School choice may be a matter of preference for certain schools, but importantly, it might also be a matter of time and space restrictions for families with fewer resources; that is, with less spatial capital and a limited opportunity structure. Results shows that travel to school distances have increased since the year 2000. Foreign-born students are travelling shorter distances, except for those with highly educated parents. Shorter distances are also travelled by students from families with social assistance and for visible minorities in areas where such minorities exist.
\end{abstract}

Keywords: travel to school, children, school choice, time geography, Sweden 


\section{Travel-to-school distances in Sweden 2000-2006: - Changing school geography with equality implications}

\section{Introduction}

In his autobiographically inspired text "Diorama, path and project", Torsten Hägerstrand gives an account of the everyday organization of a small Swedish countryside settlement during the first half of the $20^{\text {th }}$ century (1982). Hägerstrand here describes a very well-structured society in which the daily paths of individuals are governed by strong, centralized forces. In today's Sweden, many of the structures that governed people's activities then are no longer in place. Swedish schools are an important case in point.

Since the early 1990s, Sweden has put in place a liberal policy for the establishment of independent, tax-financed schools, along with extensive rights for students to select the school they want to attend. This policy has replaced a traditional system in which students were assigned to schools largely based on their place of residence. The introduction of school choice implies that children, in principle, can make decisions concerning daily travel-to-school distances in the same way that adults decide where to go to work. Advocates of school choice have argued that liberalization will lead to major benefits for both students and the school system (Lindbom 2010). They have assumed that competition between schools for students will increase educational quality. They have also pointed to school choice as a means by which the effect of residential segregation on school segregation could be mitigated (Lindbom, 2010; Vlachos 2011, p. 98). Critics of school choice, on the other hand, point to an increased risk of school segregation if there are differences in the extent to which students/parents exercise their opportunity to choose (Barthon and Monfroy, 2010; Bell, 2009; Bunar and Kallstenius, 2005; Östh, Andersson and Malmberg 2010). This problem of restrictions varying between individuals was mentioned as early as 1970 by Hägerstand in a report entitled Urbanization in Sweden: an analysis of society. He specifically mentioned children as a group facing restrictions in their daily activities and vulnerable to the quality of the educational institutions nearby (Hägerstrand, 1970, 4:31). School choice, thus, could jeopardize the ability of the school system to offer equal opportunities to students irrespective of social and ethnic background.

In this paper we propose that the effect of school choice on the educational opportunities of Swedish children can be analyzed by focusing on travel-to-school distances. By modeling how travel-to-school distances are influenced by individual factors, family background, and by the neighborhood context, it will be possible to give a more detailed picture of how school choice reshapes the social and ethnic composition of Swedish schools. This study of travel-to-school distances thus feeds into a large international research field and debate about school choice (Allen, 2007; Burgess et al., 2005; Byrne, 2009; Garcia, 2008; Harris, Johnston and Burgess 2007; Noreisch, 2007; Saporito and Lareau 1999; Seppanen 2003; Karsten et al., 2003) and changes in school systems (Alegre and Ferrer 2010; Taylor 2001; Reay 2004).

We acknowledge that a simple cross-sectional analysis of travel-to-school distances would not give any precise information on school choice. The reason is that these distances are strongly influenced by geographical factors such as the location of schools in relation to where students live, as well as the availability of transportation such as buses and subways. In order to address this problem we use a panel approach that allows us to capture the influence of geographic location with an area-specific fixed effect. This implies that locational factors that remain stable over time will not influence the parameter estimates for individual and neighborhood variables. 
Thus, in this study, the operational definition of school choice is the extent to which students choose to attend a more distant school rather than a school closer to home. A critique of this definition is that it is also possible to exercise choice between schools that are equally distant. An appropriate term for the distance-based concept could be 'geographical school choice'.

Geographical school choice can be seen to be influenced by two factors. First, the ability of students to take on the extra cost associated with longer travel-to-school distances. Recent studies of travel behavior have demonstrated that social status influences the ability of individuals to overcome the friction of distance. Although not a prominent part of Hägerstrand's original research program, the effects of class and status on mobility have received increased interest in recent time-geographic research (Chen et al., 2011; Kwan, 1998; Sang et al., 2011). The second factor is the extent to which schools farther away are considered to offer better opportunities than nearby schools.

These dimensions of school may, following Trumberg (2011), be related to the terms 'situational' and 'positional capital'. According to Trumberg, who builds his discussion on (Barthon and Monfroy, 2010; Poupeau et al., 2007), situational capital is based on the extent to which students are able to overcome the costs associated with mobility. Thus, students with high situational capital will be more able to take advantage of the opportunities offered by school choice. Positional capital, on the other hand, is based on the opportunities offered in the local environment, both in terms of actual school quality, but also of the negative or positive symbolic capital that is associated with the different areas of a city. Clearly, the idea of positional capital is related to the time-geographical concept of opportunity structure (Saegert and Winkel, 1990).

\section{Swedish educational system}

During the past two decades the Swedish educational system experienced rapid structural change. Until 1992, all comprehensive education, with very few exceptions, took place in public schools. Swedish municipalities had a great deal of self-governance, being able to locate and relocate groups of students to schools on the basis of the municipality's demographic situation, and or to create a mix of rural/urban children in the same school. However, proximity to school was the prevailing key to admission. Consequently, each school's catchment area has varied over time, but neither school nor parents have had little influence over the catchment area.

In 1992, independent schools were first introduced in Sweden. While all education remained free of charge for the students, the introduction of independent schools meant that public and non public (independent) schooling agents were paid for each student entering their school. The transition from an almost entirely public school system to a system containing several school agents spurred competition between schools. In the early years, the few independent schools available played a minor role. According to the National Agency for Education, 3.2\% of the secondary school graduates attended independent schools in year 2000. This percentage increased to $6.3 \%$ in 2003 and $8.5 \%$ in 2006 (Skolverket, 2010). While the percentages of independent school attendees remain relatively low, the choices made between public schools are non-negligible. The over-time increase of independent schools, and subsequent loss of students in public schools, has triggered fierce competition between schools (By, 2005). In order to attract students, a majority of the independent schools advertise themselves as pedagogically profiled. The profiling includes; focusing on specific school subjects (sports, language, etc.), using specific pedagogical methods (such as Montessori), or adhering to particular confessional orientations (Friskolornas Riksförbund 2010). As a response, many public schools also make use of pedagogical profiles to attract students. Common profiles among public schools include music-, drama- or sports-orientation. As a result of this increasing competition, parents and students receive advertisement from the different schools (public and independent schools), and parents fill in forms of school-choice. These choices typically are made when the child is about to start first grade, or when the student is about to leave the third, sixth or ninth grade. 
In the next section we provide a literature review. Section 3 presents a more detailed discussion of the research design and the data. In section 4 we provide parameter estimates for the main effects of individual level and neighborhood level factors, as well as parameter estimates for the interactions between individual level and neighborhood level factors. At the end there is a concluding discussion.

\section{Literature review}

Interestingly, the journey to school, its distance, the consequences for children and school composition, environmental concerns, and the actual experience of the journey are somewhat poorly researched (Sykes, 2011, p. 171). Despite this, children commuting to school is a worldwide, everyday phenomenon that takes much time and is filled with meanings and consequences. However, there are studies of children passing different social landscapes while travelling to school, especially students who have chosen a distant school (Bunar, 2010; Johansson and Hammarén, 2010). Also, studies that see schools and neighborhoods as interconnected places and as very suitable for qualitative investigations are increasing in number (Sykes, 2011; van der Burgt, 2007). Commuting-to-school distances can be used to research children's independent mobility (Fyhri and Hjorthol, 2009; Mitchell et al., 2007; Wilson et al., 2010), physical health factors (such as obesity, air pollution) (Pooley et al., 2010) or other aspects of children's daily lives in today's society (Johansson and Hammarén, 2010; Pooley et al., 2005; Tillberg, 2001).

In this section we will start with the issue of distance to school. The second part considers factors that have been shown in earlier research to influence the distance and choice of school.

\subsection{Commuting to school}

McDonald's (2007) study confirmed increases in distance to school and provided results from the US National Personal Transportation Survey between the years 1969 to 2001. The increase in distance could account for half of the decline in active transportation to school (biking, walking) (McDonald, 2007); children were driven to school instead. The study, like many others, investigates distance to school with the purpose of discussing increasing obesity among children (Fyhri and Hjorthol, 2009). In this vein, policies designed to encourage schools to be placed within neighborhoods to ensure walking distance have been requested.

Also, commuting to school is increasingly seen as something parents have to help out with for safety, and distance reasons. However, a study of children in Auckland, New Zealand found that most children wanted to travel independently to school (Mitchell et al., 2007). Independent travel could be seen as hindered by increasing distance to school (Wilson et al., 2010). Children with an increased distance to travel to school will probably feel less independent, and leisure time will decrease. Other researchers focus on the lesser feel for landscape and environment while travelling far, especially by car (Fyhri and Hjorthol, 2009; Pooley et al., 2010). Related research issues showing problems with increasing distances to school are environmental goals and costs for municipalities in cases where children are entitled to school transport.

Concerning distance to school, there are few studies directly aimed at analyzing the ability/possibility of overcoming space restrictions in order to retain an unlimited choice. However, a close analysis of school choice in Örebro in Sweden showed increased mobility in case studies (Trumberg, 2011). Since this study was conducted in one middle-sized town, its generalizability is limited.

\subsection{Factors that influence the length of travel and school choice}

In the literature on school-commuting there are a number of factors that are considered particularly important. These factors are found in both qualitative as well as quantitative studies. However, when 
turning to studies beyond the actual school-commuting distance, there is a wealth of studies concerning who chooses a school other than the local/nearest school, and why. Therefore, we will also turn to this literature (a sample of studies) to explain and show assumptions for the variables chosen in this study.

A topic that has gained much attention in the school choice literature is ethnicity/race (born abroad self or parents) (Andre-Bechely, 2007; Karsten et al., 2003; Saporito, 2003). The matter of segregation between schools is a longstanding issue that has gained new attention with the increased school choice policies in the Western world. Among others, Andre-Bechely states that race is not independent when it comes to spatial practice (Andre-Bechely, 2007). He investigated schoolcommuting in Los Angeles and found that busing mostly affected the poor Latinos and African American population. The areas where they lived were increasing in population size, so local school populations were capped. In addition, integration is a vital part of schooling policy, which also results in busing. During the 1980s and 1990s, busing increased in the large metropolitan areas in the US and the costs were running out of control. Charter schools in neighborhoods from which many students were bussed changed the picture, and in addition, school choice programs did not provide transport. Now another side of restrictions was seen; poor parents who did not have a car or could not afford travel could not make use of the school choice (Andre-Bechely, 2007). Wilson et al. also found different concerns for nonwhite and white parents in availability of bus service and safety . (2010) Nonwhite children did ride the bus to a greater extent than did white children (Wilson et al., 2010, p. 2182). Andre-Bechely concludes that well-intentioned policy makers constructing the school choice program might unknowingly reinforce the historical race inequalities in US society. The geographical context in which the choices are made, together with parents with few resources, are the reasons for this.

In Sweden there is no tradition of busing and the school system is different from that in the US. Also, the black/white division is not present. However, there are foreign-born students that might deserve extra attention in that language barriers as well as knowledge about the school choice process alternatives may be limited. Therefore, foreign-born as well as visible minorities are considered in regard to commuting distance in our study.

In a recent study, Trumberg (2011) showed that foreign-born students did not chose to change from the closest to home school to the same extent as did Swedish-born students in Örebro municipality. This pattern in the choice process made some schools uniform concerning foreign-born students (see Andersson, Östh, Malmberg 2010 for Swedish school segregation). In addition, students with high educational, economic and cultural capital were choosing other schools than the local one, often schools in the city center of Örebro (Trumberg, 2011). School choice showing sorting on ethnicity, class and educational level of parents is found in many studies such as Noreisch (2007), Saporito and Lareau (1999) , Karsten et al., (2003), Burgess et al., (2005) and Reay (2004).

In the above mentioned report on urban areas in Stockholm it was shown that students whose families had received social assistance or a housing allowance commuted shorter distances than students in families that had never received social assistance or a housing allowance (Bunar and Kallstenius, 2005, p. 32). In the same report it was shown that students with employed parents also commuted to a higher degree than those with unemployed parents. Though these results come from a limited set of urban areas in a specific metropolitan region, we intend to study financial resources using the variable social assistance across Sweden.

Also important in many studies of the commuting distance of students is the educational level of parents. Some studies show that students with higher educated families commuted longer (Bunar and Kallstenius, 2005). We also considered results from the school perspective, which showed that the lower performing schools recruit students from a much more narrowly defined catchment area (Butler et al., 2007; Trumberg, 2011). The opposite of course is that schools with higher performing 
students recruit students from a wider geographical area. We have included post upper secondary education to test educational level on travel to school distance.

The pattern of distance to school is a reflection of the residential patterns of schoolchildren. In Walford, choosing a school is regulated by 'choosing by mortgage' (Walford, 2003), that is, property prices and tenure type are important. A study by Holme (2002) shows parents make the choice on the assumed status of the school based on the status of students and parents attending the particular school. The information of 'good' schools were found in parents' social network and not in schools curricula, test scores or by visiting the new school. On these so called social constructions of school quality households did 'buy school' via buying a home (Holme, 2002). In this way some researchers blame the sorting into different neighborhoods (mostly due to housing prices and where public housing is located) as the main reason for 'skimming the cream', and not the school choice (Lankford and Wyckoff, 2001; Lindbom and Almgren, 2007). In this study we control for effects from the neighbourhood level, post migration that is, we take the home location of students' as given. Tenure form of students and residential area are tested in our study.

An interesting complement to our quantitative approach is a Swedish interview study of noncommuters in two stigmatized, immigrant-dense urban schools (Bunar, 2010). The schools in this study were located in areas that qualify for assistance from central government, sometimes called distressed areas. Many students had chosen another school instead of the "low-performing", "highpoverty" school with a bad reputation, as the author described the studied schools (Bunar, 2010, p. 142). However, the interviewed students, who were 14 to 17 years of age, liked the school, felt safe among other immigrants, and did not want to run the risk of being seen as 'different' in a 'Swedish' majority school. The author concluded that neither deficiency in information, nor transportation costs, nor time was behind the decision to stay, i.e. the decision was not linked to having fewer resources; in the terminology of time geography, no constraints were important. Also studying youth in immigrant-dense neighborhoods, Johansson and Hammarén came to a related conclusion about the students feeling different in an inner city school (Johansson and Hammarén, 2010). The choice of attending an inner-city school made both an economic and social change possible but revealed existing class and gender structures (Johansson and Hammarén, 2010). In a study of gentrifiers in London the same idea about feeling safe among children of the same backgound was found (DeSena, 2006). Gentrifiers were according to the author rejecting both local physical and social space when sending their children to schools in other neighbourhoods.

Bunar's result contrasts with our ideas about spatial capital and geographical accessibility varying with resources and socio-economic position (Bunar, 2010). On one hand, a tempting criticism is the high age of interviewed students; does it still offer a choice situation? (This would explain the rationale for liking the school and feeling safe with classmates). And the author's immediate inclination of preferences as a cause of staying, and rejecting limited resources. On the other hand, the result can be seen as complementing our knowledge from another perspective; there are aspects of the choice mechanism that are impregnated with the duality of the Swedish school system in terms of ethnicity. Students staying in their low-performing, poverty schools, is a sign of resisting the choice situation, and resisting choice on unequal terms, as the author points out (Bunar, 2010). A choice may mean isolating oneself from social networks in the neighborhood of residence in order to access a better performing school. From the perspective of finding reasons behind differences in commuting distances to school, this would at least imply taking into account the neighborhood as a context.

\section{Data and research design}

Our analysis of travel-to-school distances is based on a database that contains information on all Swedish students graduating from middle-school (9th grade) in 2000, 2003, and 2006. For these students we have 100 meter square grid coordinates for the location of their school and the location 
of their residence, allowing us to compute Euclidean travel-to-school distances. In addition we have data on student country-of-birth, parent country-of-birth, parental education, martial status of household head, household recipiency of social assistance, and type of dwelling.

Not included in the sample are three types of students. (1) Students that have changed residence in their year of graduation. These are excluded because residence is registered only once a year, in December, whereas graduation is in June. (2) Students whose registered residence is more than 100 $\mathrm{km}$ away from their school of graduation. (3) Students living with one parent and for whom the school is closer to the residence of their other parent.

+HÄNVISNING TILL TABELL 1

LÄGGA DESCRIPTIVES TABELL HÄR

A key assumption of our analysis is that students exercising school choice have longer travel-toschool distances than no-choice students from the same neighborhood. In order to implement this approach empirically we have, first, assigned students to $5 \mathrm{~km}$ squares based on the location of their residence. Second, using the panel data set described above we have estimated a regression model with (log) travel-to-school distance as the dependent variable, and four types of explanatory variables: individual level variables, neighborhood contextual variables, period fixed-effect variables and neighborhood fixed-effect variables.

In this analysis, the neighborhood fixed-effect variables play a key role. Mathematically, fixed effect estimation is equivalent to a regression on data from which the subgroup means of both dependent and the explanatory variables have been removed. If the subgroup consists of students living in the same $5 \times 5 \mathrm{~km}$ square, mean travel-to-school distance will be influenced by a number of factors that are related to the local and extra-local supply of school opportunities, including the influence of transport infrastructure on the accessibility of distant schools. When the subgroup mean has been removed, the remaining variation in travel-to-school distance will not be influenced by time-invariant differences in school supply. Instead it will reflect within-neighborhood, between-individual variation in the extent to which distant schools are chosen above close-to-home schools. Thus, the use of neighborhood fixed-effects allows us to use travel-to-school distances as a measure of school choice. Estimating a fixed effect of location on travel-to-school distance is in some ways comparable to the estimation of a multilevel model with students aggregated to $5 \times 5 \mathrm{~km}$ squares.

A restriction on this approach is that we need a minimum number of observations per location in order to get reasonable estimates of the location fixed effect. Sweden's total surface contains approximately $17480,5 \times 5$ kilometers squares of which 6,976 were populated with students during the studied years. 1,126 of these squares had at least 20 graduating students, a number we have judged to be a minimum for allowing the estimation of a location fixed effect.

The left part of the Figure 1 below shows the squares that have below 20 students (blue) and at least 20 students (black). The right part of the figure displays students' mean commuting distances. Red colors indicate shorter distances, while yellow distances indicate longer distances. Both the left and right parts of the figure contain blowups of the population-dense regions surrounding Stockholm. The reduction in the number of studied regions is great, but the number of students dropped is much less. The total number of graduating students during the three years equals 331,236 and the number of students included in our analyses after adjusting for students moving during the year of graduation, students travelling more than 100 kilometers, and students residing in low populated $5 \mathrm{~km}$ times $5 \mathrm{~km}$ units, amounts to 221,846 . Consequently, approximately one third of the students were deleted from our analyses.

Given the inclusion of fixed area effects, it is straightforward to estimate the effects of individual level variables on travel-to-school distances. In this study we do this by including dummy variables 
for ethnic background, gender, high education, single parent status, social benefit reception, and housing type. In addition to the individual level variables we are also interested in the extent to which the population composition of the local area influences travel-to-school distances. To investigate this we have used aggregate measures based on the individual-level variables. These measures include the proportion of foreign-born people in the graduated student population of the area, the proportion of visible minorities among students, the proportion of students with highly educated parents, etc.

However, we also include interactions between the individual-level variables and the composition variables. The motivation for including interactions is that the effect of one contextual variable is not necessarily the same across different types of individuals.
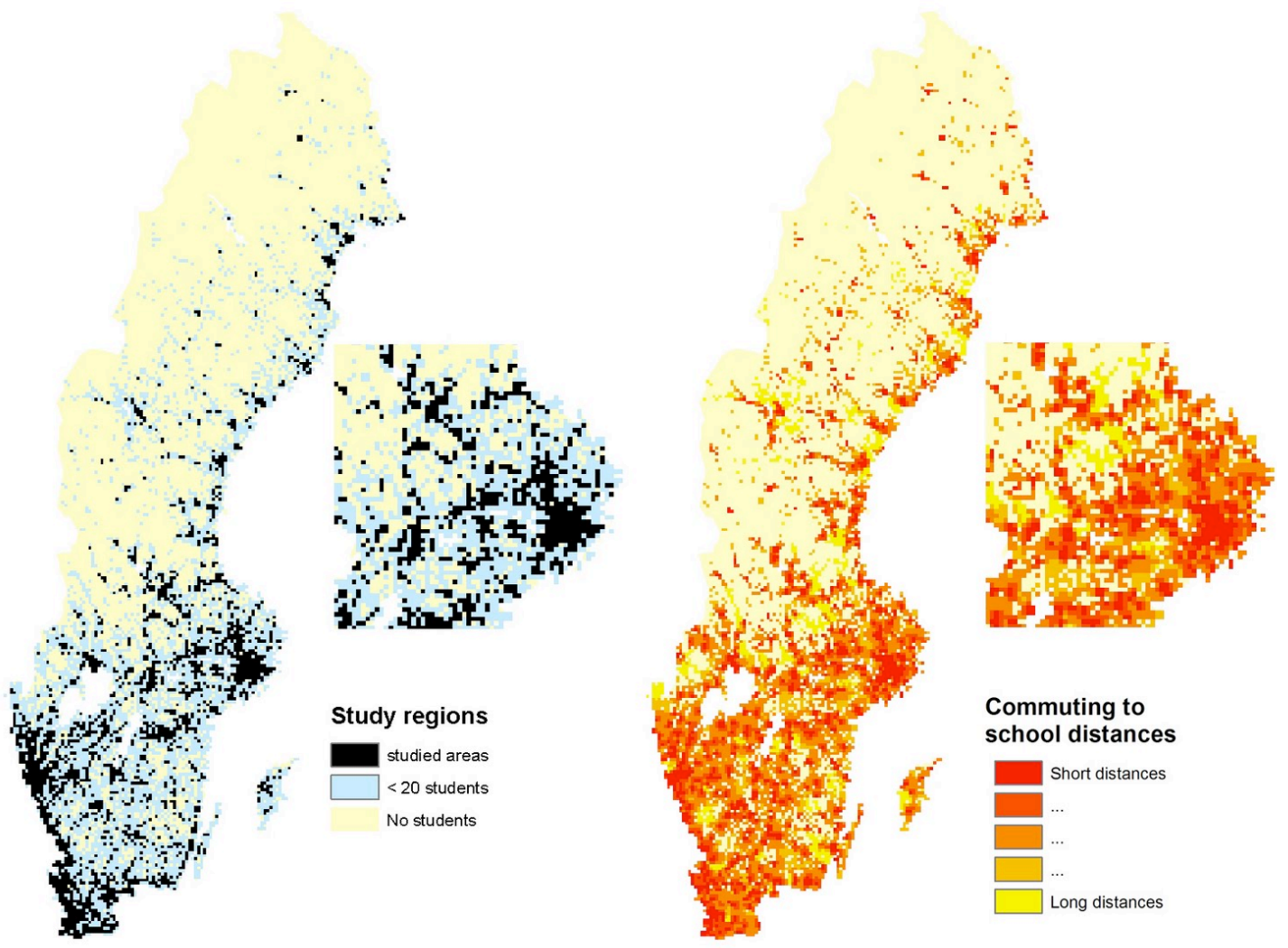

Figure 1. Study regions and commuting to school distances.

\section{Results}

In the following we show the results from fixed effect panel estimations with individual and context variables on travel to school distance. The estimates are presented in two tables, namely: individual variables in Table 2, and adding context variables as well as interaction-effect estimates in Table 3. The main result of the models run is that the distance to school increases from the year 2000 through the year 2003 until 2006. The estimates are significant and show an increase in the distance of about 32 percent for individuals in our sample. These results point to increasing school choice during the period studied.

The estimates in Table 2 also show that being born abroad is associated with shorter distance to school than being born in Sweden. Likewise, visible minority students had a shorter distance to 
school compared to students not belonging to a visible minority group. This might be a sign that parents of these students have fewer resources concerning both time and costs for transportation, and lack information about available alternatives. However, newly arrived immigrant students commute slightly longer distances than other students. This might be explained by the tendency of Swedish municipalities to concentrate resources of Swedish language training on certain schools, and not always on the school closest to home.

Another result is that girls tend to travel longer distances than boys in our study. This result is consistent with earlier research on choosing schools (Trumberg, 2011). Yet another significant characteristic for students travelling far to school is that they have parents with post-upper secondary education. According to our analysis they travel a 5 percent longer distances than students with less highly educated parents, see Table 2.

Table 2. Individual variable estimates for travel to school distance.

\begin{tabular}{|c|c|c|c|c|}
\hline Term & Estimate & Std Error & t Ratio & Prob $>|t| \mid$ \\
\hline Intercept & 7.290 & 0.008 & 897.950 & 0.000 \\
\hline Foreign born & -0.072 & 0.007 & -10.390 & $<.0001$ \\
\hline Visible minority (VM) & -0.035 & 0.010 & -3.350 & 0.001 \\
\hline Newly arrived immigrant & 0.035 & 0.008 & 4.200 & $<.0001$ \\
\hline Female & 0.027 & 0.004 & 6.870 & $<.0001$ \\
\hline Post upper secondary edu. (high edu) & 0.051 & 0.004 & 12.610 & $<.0001$ \\
\hline Social assistance & -0.114 & 0.008 & -13.710 & $<.0001$ \\
\hline Single parent & 0.005 & 0.004 & 1.060 & 0.290 \\
\hline Owner occupation & 0.259 & 0.007 & 38.020 & $<.0001$ \\
\hline Tenant cooperative & 0.085 & 0.009 & 9.660 & $<.0001$ \\
\hline High edu. $-0.482 * \mathrm{~F}$. born 0.174 & 0.112 & 0.011 & 10.510 & $<.0001$ \\
\hline Year[2000] & -0.028 & 0.003 & -9.800 & $<.0001$ \\
\hline Year[2003] & 0.008 & 0.003 & 2.860 & 0.004 \\
\hline
\end{tabular}

The estimates also show that financial hardship (social assistance) has a negative effect on travel-toschool distancce. Yet another possible sign of compromised ability to execute choice could be if a student is living with a single parent. However, our estimates showed this was not significant on the outcome distance to school.

In Table 2 we included three variables of tenure forms; owner occupation, tenant cooperative and rental housing (reference). However, the parameters should not be interpreted as social characteristics of students, but rather as controls for different types of housing located differently within the five times five kilometer square. Owner occupation is practically the same as single family housing/detached housing and thus located further away from schools in general. The parameter shows longer distances to school for students in this type of housing compared to students in rental housing (often equal to multifamily dwellings). Equally, tenant cooperative housing (often multifamily housing, but cooperatively owned) is located somewhere 'in between' owner occupation and rental housing and thus gives the result of intermediate, distance to school, thus is not necessarily an indication of school choice.

Finally, the estimated parameter for the interaction between foreign-born and parents with postsecondary education is positive (FÖRKLARA SJÄLVA SIFFRAN). This implies that for foreign-born students having a parent with post-secondary education has an even stronger effect on commuting distances than for Swedish-born students. 
In the model presented in Table 3 area-level aggregate variables for the $5 \times 5 \mathrm{~km}$ squares are added to the individual level variables. Including aggregate variables does not change the estimated parameter for the individual level variables very much, but we find the aggregate variables also have an effect on travel-to school distances. First, an increasing share of foreign born, as well as an increasing share of visible minorities in the neighborhood is associated with longer school commutes. The effect of neighborhood compositions varies depending on student status, though. This is shown by the estimates for the interaction variables foreign-born share crossed with foreign born status and visible minority share crossed with visible minority status. These estimates are negative and this indicates that it is mainly for Swedish-born and non-visible minorities that higher foreign born shares and higher visible minority shares have the effect of increasing travel-to-school distances. This is not the case for foreign born and visible minority students respectively. This result naturally connects to the research field of schools and white flight (Clark, 1987; Clotfelter, 1976).

Table 3. Full model with individual and neighborhood variable estimates on travel to school distance.

\begin{tabular}{|c|c|c|c|c|}
\hline Term & Estimate & Std Error & t Ratio & Prob $>|t|$ \\
\hline Intercept & 7.629 & 0.073 & 104.030 & 0.000 \\
\hline Foreign born & -0.053 & 0.009 & -5.950 & $<.0001$ \\
\hline Visible minority (VM) & 0.014 & 0.014 & 1.000 & 0.317 \\
\hline Newly arrived immigrant & 0.025 & 0.010 & 2.570 & 0.010 \\
\hline Female & 0.024 & 0.004 & 5.440 & $<.0001$ \\
\hline Post upper secondary edu. (high edu) & 0.054 & 0.005 & 11.590 & $<.0001$ \\
\hline Social assistance & -0.069 & 0.010 & -7.110 & $<.0001$ \\
\hline Single parent & 0.008 & 0.005 & 1.670 & 0.094 \\
\hline Owner occupation & 0.252 & 0.008 & 32.160 & $<.0001$ \\
\hline Tenant cooperative & 0.078 & 0.010 & 7.720 & $<.0001$ \\
\hline High edu.-0.482*F. born- 0.174 & 0.107 & 0.012 & 8.760 & $<.0001$ \\
\hline Share VM & 1.407 & 0.148 & 9.510 & $<.0001$ \\
\hline Share F. born & 0.214 & 0.099 & 2.160 & 0.031 \\
\hline Share VM-0.059*VM-0.058 & -0.950 & 0.175 & -5.440 & $<.0001$ \\
\hline Share F. born-0.172*F. born- 0.173 & -0.455 & 0.069 & -6.600 & $<.0001$ \\
\hline Share high edu & -0.576 & 0.054 & -10.590 & $<.0001$ \\
\hline Share social assistance & 0.518 & 0.112 & 4.630 & $<.0001$ \\
\hline Share social assistance- $0.075 * \mathrm{~F}$. born- 0.173 & -0.855 & 0.139 & -6.140 & $<.0001$ \\
\hline Share owner occupation & -0.090 & 0.080 & -1.120 & 0.264 \\
\hline Share owner occupation- $0.739 *$ F. born- 0.173 & -0.355 & 0.044 & -8.080 & $<.0001$ \\
\hline Year[2000] & -0.118 & 0.004 & -30.290 & $<.0001$ \\
\hline Year[2003] & -0.048 & 0.003 & -14.850 & $<.0001$ \\
\hline
\end{tabular}

We also analyzed the proportion of parents in the neighborhood with post-upper secondary education, which is a high educational level. Here the association was the more educated the parents, the shorter the distances to school. Next, the proportion of families receiving social assistance increased the distance to school. This result would contradict the idea of students in such areas having less opportunities to choose a more distant/high reputation school. However when this variable was further crossed with foreign-born people the result showed that the distance was shorter for foreign-born people in areas with many people receiving social assistance; therefore the 
interpretation is that Swedish born people choose a school at a greater distance in neighborhoods with many families on social assistance. Again, there is the difference in student individual status deciding how the option to choose is used.

There is an increase in the distance travelled by school children between the years, as shown by the variables year 2000, 2003 and reference 2006.

Our model demonstrates that the higher the proportion of owner occupation in a neighborhood, the shorter the distance to school for students, as shown in Table 3. Few students choose another, more distant school. However, if we look at the interaction effect of owner occupation and foreign-born people we conclude that foreign-born students living in owner occupation stay at the local school to an even higher degree than Swedish born students.

In order to test the variable 'travel to school distances' used in the analyses, an alternative specification of distance has been used. Since the locations of homes and schools are known for all graduating students, it is possible to create a variable counting the number of schools located between the residential location of every student and the chosen school. Results from regressions making use of this alternative dependent variable are similar to the results presented above. Assuming that the distribution of schools is determined by the locations of students, the results make sense. Choosing to attend another school than the neighbourhood school almost always means increasing commuting distance, and as long as schools are located to serve a local pool of children, choosing a more distant schools also means choosing to commute over school catchment borders. Due to similarities between regression estimates, the results from regression making use of the alternative specification of the dependent variable are not presented (available upon request).

\section{Concluding discussion}

In this paper we have used travel-to-school distances to explore the effect of school choice on the Swedish educational system. In the introduction we proposed that if our findings showed that geographical school choice was not influenced by individual or neighborhood level social and ethnic factors this would provide an argument for providing liberalized school choice as a means to increase educational equity. Our results, however, show that this ideal situation does not exist in the Swedish case. The distance to school travelled by children in our study is influenced by both individual factors as well as neighbourhood factors which creates school choice on unequal terms.

First, there is a general trend that disadvantaged ethnic and social groups have a lower mobilitypositional capital than less disadvantaged groups. Therefore, the constraints on using school choice to improve educational opportunities are greater for foreign-born and visible-minority students, for students from families without higher education, and for students from families receiving social assistance. This means that shorter distances travelled is a constraint and not convenience.

Among foreign-born students, those from families with higher education have a higher positional capital. The longer distance might in this case be seen as an opportunity to reach higher status/ better quality education. A similar result has been shown by Bunar and Kallstenius (2005) for immigrant-dense urban areas in Stockholm. This could be explained by resources, financial as well as other types, or by the degree to which foreign-born and visible minorities have acquired situational and positional capital. However, differences in resources such as time, transportation costs or information are rejected by Bunar in a later study (2010). If the reason to stay and go to school in a stigmatized area is not caused by lack of resources it might be a sign of resistance. A student being forced to travel far to acquire high quality schooling can in this case be perceived as oppression and not an opportunityon equal terms. The mentioned forms of situational and positional capital are, however, further developed to be capitals in their own right, unequally distributed among social groups (Barthon and Monfroy, 2010)

Second, there are significant area-level effects of social and ethnic composition on mobility. Thus, there is a significant tendency for students of non-visible minority background to choose more 
distant schools if their local area has a high proportion of visible minority students. The same pattern can be seen among Swedish-born students in areas with a high proportion of foreign-born students. Moreover, Swedish born students have a tendency to select more distant schools if their residential area has a large proportion of students whose families are on social assistance.

However, in areas where there are many students from families with higher education, the tendency to choose more distant schools is weaker. In this case short distances is not a constraint, rather showing that student is well placed in space, having high positional capital. A similar pattern can be observed in neighborhoods with a high proportion of owner-occupied housing, at least for foreignborn students. In summary the actual distances travelled by students have to be analysed together with the knowledge of social and ethnic group status as well as the knowledge of social and ethnic composition in the area of residence.

These patterns of differential mobility imply that geographical school choice has the effect of depleting local schools in disadvantaged areas of students with a less disadvantaged background. Restrictions for students create different opportunity structures concerning education. Instead of promoting equity, this study thus provides strong evidence that liberalized school choice has led to a substantial reduction in equity in the Swedish school system.

\section{References}

Alegre, M.A., Ferrer, G., 2010. School regimes and education equity: some insights based on PISA 2006. British Educational Research Journal 36, 433 - 461.

Allen, R., 2007. Allocating Pupils to Their Nearest Secondary School: The Consequences for Social and Ability Stratification. Urban Stud 44, 751-770.

Andersson, E., Östh, J., Malmberg, B., 2010. Ethnic segregation and performance inequality in the Swedish school system: a regional perspective. Environment and Planning A 42, 2674-2686.

Andre-Bechely, L., 2007. Finding Space and Managing Distance: Public School Choice in an Urban California District. Urban Stud 44, 1355-1376.

Barthon, C., Monfroy, B., 2010. Sociospatial Schooling Practices: A Spatial Capital Approach. Educational Research and Evaluation 16, 177-196.

Bell, C.A., 2009. All Choices Created Equal? The Role of Choice Sets in the Selection of Schools. Peabody Journal of Education (0161956X) 84, 191-208.

Bunar, N., 2010. The Geographies of Education and Relationships in a Multicultural City. Acta Sociologica 53, 141-159.

Bunar, N., Kallstenius, J., 2005. I min gamla skola lärde jag mig fel svenska. En studie om skolvalfrihet i det polariserade urbana rummet (In my old school I leart the wrong Swedish language. A study of free school choice in the polarised urban space). Integrationsverket, Stockholm.

Burestam, S., 2007. Elevströmmar i Stockholms stad 1998-2005 (Streams of students in Stockholm municipality 1998-2005). USK, utrednings- och statistikkontoret, Stockholm.

Burgess, S., McConnell, B., Propper, C., Wilson, D., 2005. The Impact of School Choice on Sorting by Ability and Socio-economic Factors in English Secondary Education. CMPO, University of Bristol, Bristol. http://www.efm.bris.ac.uk/ecsb/papers/book_chapter.pdf

Butler, T., Hamnett, C., Ramsden, M., Webber, R., 2007. The best, the worst and the average: secondary school choice and education performance in East London. Journal of Education Policy 22,7 - 29.

By, U., 2005. En av fem går i skola långt bort (One in five in a school far away). Interview with Nihad Bunar, Dagens Nyheter, Stockholm, pp. http://www.dn.se/sthlm/en-av-fem-gar-i-skola-langtbort-1.410989

Byrne, B., 2009. Not just class: towards an understanding of the whiteness of middle-class schooling choice. Ethnic and Racial Studies 32, 424-441. 
Chen, J., Shaw, S.-L., Yu, H., Lu, F., Chai, Y., Jia, Q., 2011. Exploratory data analysis of activity diary data: a space-time GIS approach. Journal of Transport Geography 19, 394-404.

Clark, W.A.V., 1987. School desegregation and white flight: A reexamination and case study. Social Science Research 16, 211-228.

Clotfelter, C.T., 1976. School Desegregation, "Tipping," and Private School Enrollment. The Journal of Human Resources 11, 28-50.

DeSena, J.N., 2006. "What's a Mother To Do?". American Behavioral Scientist 50, 241-257.

Friskolornasriksförbund, 2009. (Swedish Association of Independent Schools) http://www.friskola.se/ Om_oss_In_English_DXNI-38495_.aspx.

Fyhri, A., Hjorthol, R., 2009. Children's independent mobility to school, friends and leisure activities. Journal of Transport Geography 17, 377-384.

Garcia, D.R., 2008. Academic and Racial Segregation in Charter Schools: Do Parents Sort Students Into Specialized Charter Schools? Education and Urban Society 40, 590-612.

Hagerstrand, T., 1982. Diorama, Path and Project. Tijdschrift voor economische en sociale geografie 73, 323-339.

Harris, R., Johnston, R., Burgess, S., 2007. Neighborhoods, Ethnicity and School Choice: Developing a Statistical Framework for Geodemographic Analysis. Population Research and Policy Review 26, 553-579.

Holme, J.J., 2002. Buying Homes, Buying Schools: School Choice and the Social Construction of School Quality. Harvard Educational Review 72, 177-206.

Hägerstrand, T., 1970. Tidsanvändning och omgivningsstruktur, In: universitet, G.i.L. (Ed.), Urbaniseringen i Sverige, en geografisk samhällsanalys. SOU 1970:14. Allmänna förlaget, Stockholm.

Johansson, T., Hammarén, N., 2010. Konsten att välja rätt spårvagn. En studie av segregation, skolval och unga människors studieplaner (The art of choosing the right tram - A study of urban segregation, choice of school and young people's life plans). Sociologisk forskning 47.

Karsten, S., Ledoux, G., Roeleveld, J., Felix, C., Elshof, D., 2003. School Choice and Ethnic Segregation Educational Policy 17, 452-477.

Kwan, M.-P., 1998. Space-Time and Integral Measures of Individual Accessibility: A Comparative Analysis Using a Point-based Framework. Geographical Analysis 30, 191-216.

Lankford, H., Wyckoff, J., 2001. Who would be left behind by enhanced private school choice? Journal of Urban Economics 50, 288-312.

Lindbom, A., Almgren, E., 2007. Valfrihetens effekter på skolornas elevsammansättning: Skolsegregationen i Sverige, In: Lindbom, A. (Ed.), Friskolorna och framtiden -segregation, kostnader och effektivitet. Institutet för framtidsstudier, Stockholm, pp. 89-119.

McDonald, N.C., 2007. Active transportation to school - Trends among US schoolchildren, 1969-2001. American Journal of Preventive Medicine 32, 509-516.

Mitchell, H., Kearns, R.A., Collins, D.C.A., 2007. Nuances of neighbourhood: Children's perceptions of the space between home and school in Auckland, New Zealand. Geoforum 38, 614-627.

Noreisch, K., 2007. School catchment area evasion: the case of Berlin. Journal of Education Policy 22, 69-90.

Pooley, C., Whyatt, D., Walker, M., Davies, G., Coulton, P., Bamford, W., 2010. Understanding the school journey: integrating data on travel and environment. Environment and Planning A 42, 948-965.

Pooley, C.G., Turnbull, J., Adams, M., 2005. The journey to school in Britain since the 1940s: continuity and change. Area 37, 43-53.

Poupeau, F., Francois, J.C., Couratier, E., 2007. Making the right move: how families are using transfers to adapt to socio-spatial differentiation of schools in the greater Paris region. Journal of Education Policy 22, 31-47.

Reay, D., 2004. Exclusivity, Exclusion, and Social Class in Urban Education Markets in the United Kingdom. Urban Education 39, 537-560.

Saegert, S., Winkel, G.H., 1990. Environmental Psychology. Annual Review of Psychology 41, 441-477.

Sang, S., O’Kelly, M., Kwan, M.-P., 2011. Examining Commuting Patterns. Urban Studies 48, 891-909. 
Saporito, S., 2003. Private Choices, Public Consequences: Magnet School Choice and Segregation by Race and Poverty. Social Problems 50, 181-203.

Saporito, S., Lareau, A., 1999. School Selection as a Process: The Multiple Dimensions of Race in Framing Educational Choice. Social Problems 46, 418-439.

Schelling, T.C., 1978. Micromotives and macrobehavior. Norton, New York.

Seppanen, P., 2003. Patterns of 'public-school markets' in the Finnish comprehensive school from a comparative perspective. Journal of Education Policy 18, 513-531.

Skolverket, 2010. Rustad att möta framtiden? PISA 2009 om 15-åringars läsförståelse och kunskaper i matematik och naturvetenskap (Prepared to meet the future? PISA 2009 on15 yearolds' reading, maths and science abilities) Reports. Skolverket (Swedish national agency for education), Stockholm, no. 352.

Sykes, B., 2011. One-sided geographies? The interplay among youth, neighbourhoods and schools, In: Sykes, B. (Ed.), Spatial order and social position: Neighbourhoods, schools and educational inequality. University of Amsterdam, Amsterdam.

Taylor, C., 2001. The geography of choice and diversity in the 'new' secondary education market of England. Area 33, 368-381.

Tillberg, K., 2001. Barnfamiljers dagliga fritidsresor i bilsamhället - ett tidspussel med geografiska och könsmässiga variationer (Daily leisure trips of families with children in a car-based society - a time puzzle involving geographical and gender differences), Kulturgeografiska institutionen. Uppsala universitet, Uppsala.

Trumberg, A., 2011. Den delade skolan. Segregationsprocesser i det svenska skolsystemet [Divided schools. Processes of segregation in the Swedish school system]. Örebro University, Örebro, p. 325.

Walford, G., 2003. School Choice and Educational Change in England and Wales, In: Plank, D.N., Sykes, G. (Eds.), Choosing Choice: School Choice in International Perspective. Teachers College Press, Amsterdam, New York, pp. 68-92.

van der Burgt, D., 2007. "Där man bor tycker man det är bra": Barns geografier i en segregerad stadsmiljö ("Where you live you like it": Children's Geographies in a Segregated Urban Environment), Kulturgeografiska institutionen, Geografiska regionstudier $\mathrm{nr} 71$. Uppsala universitet, Uppsala.

Wilson, E.J., Marshall, J., Wilson, R., Krizek, K.J., 2010. By foot, bus or car: children's school travel and school choice policy. Environment and Planning A 42, 2168-2185.

Vlachos, J., 2011. Friskolor i förändring (Independant schools and change), In: Hartman, L. (Ed.), Konkurrensens konsekvenser : vad händer med svensk välfärd (Consequences of competition: What happens with Swedish welfare). SNS Förlag Stockholm, pp. 66-110.

Östh, J., Andersson, E., Malmberg, B., 2010. School choice and increasing performance difference: a counterfactual approach. Dept of Sociology, Demography Unit, Stockholom, p. 28. 